\title{
A case report of individualized ventilation in a COVID-19 patient - new possibilities and caveats to consider with flow- controlled ventilation
}

Patrick Spraider ${ }^{1 *}$, Gabriel Putzer ${ }^{1}$, Robert Breitkopf ${ }^{1}$, Julia Abram¹, Simon Mathis ${ }^{1}$, Bernhard Glodny ${ }^{2}$ and Judith Martini ${ }^{1}$

\begin{abstract}
Background: Flow-controlled ventilation (FCV) is a novel ventilation method increasingly being used clinically, particularly during the current COVID-19 pandemic. However, the continuous flow pattern in FCV during inspiration and expiration has a significant impact on respiratory parameters and ventilatory settings compared to conventional ventilation modes. In addition, the constant flow combined with direct intratracheal pressure measurement allows determination of dynamic compliance and ventilation settings can be adjusted accordingly, reflecting a personalized ventilation approach.

Case presentation: A 50-year old women with confirmed SARS-CoV-2 infection suffering from acute respiratory distress syndrome (ARDS) was admitted to a tertiary medical center. Initial ventilation occurred with best standard of care pressure-controlled ventilation (PCV) and was then switched to FCV, by adopting PCV ventilator settings. This led to an increase in oxygenation by $30 \%$. Subsequently, to reduce invasiveness of mechanical ventilation, FCV was individualized by dynamic compliance guided adjustment of both, positive end-expiratory pressure and peak pressure; this intervention reduced driving pressure from 18 to $12 \mathrm{~cm} \mathrm{H} \mathrm{H}_{2} \mathrm{O}$. However, after several hours, compliance further deteriorated which resulted in a tidal volume of only $4.7 \mathrm{ml} / \mathrm{kg}$.

Conclusions: An individualized FCV approach increased oxygenation parameters in a patient suffering from severe COVID-19 related ARDS. Direct intratracheal pressure measurements allow for determination of dynamic compliance and thus optimization of ventilator settings, thereby reducing applied and dissipated energy. However, although desirable, this personalized ventilation strategy may reach its limits when lung function is so severely impaired that patient's oxygenation has to be ensured at the expense of lung protective ventilation concepts.
\end{abstract}

Keywords: Respiratory Distress Syndrome, Adult, COVID-19, Case Report, Lung Compliance, Stress Mechanical

\footnotetext{
* Correspondence: patrick.spraider@i-med.ac.at

'Department of Anaesthesiology and Intensive Care Medicine, Medical

University Innsbruck, Innsbruck, Austria

Full list of author information is available at the end of the article
}

(c) The Author(s). 2021 Open Access This article is licensed under a Creative Commons Attribution 4.0 International License, which permits use, sharing, adaptation, distribution and reproduction in any medium or format, as long as you give appropriate credit to the original author(s) and the source, provide a link to the Creative Commons licence, and indicate if changes were made. The images or other third party material in this article are included in the article's Creative Commons licence, unless indicated otherwise in a credit line to the material. If material is not included in the article's Creative Commons licence and your intended use is not permitted by statutory regulation or exceeds the permitted use, you will need to obtain permission directly from the copyright holder. To view a copy of this licence, visit http://creativecommons.org/licenses/by/4.0/. The Creative Commons Public Domain Dedication waiver (http://creativecommons.org/publicdomain/zero/1.0/) applies to the data made available in this article, unless otherwise stated in a credit line to the data. 


\section{Background}

An inherent problem of artificial ventilation is the difficulty to precisely assess individual lung mechanics from ventilation parameters and displayed measurements, knowing that setting the ventilator based on body weight does not adequately address variations in lung mechanics. This fact is especially critical in severely ill patients such as patients suffering from SARS-CoV-2 associated acute respiratory distress syndrome (ARDS) [1-3]. Flowcontrolled ventilation (FCV) is a novel ventilation mode which, due to its constant flow and direct intratracheal pressure measurement, enables accurate measurement of dynamic compliance. In the following article we would like to demonstrate by means of a case report how individualized ventilation with compliance guided pressure settings can be performed with FCV, thereby reducing the risk of ventilator induced lung injury on the one hand and improving ventilation efficiency on the other.

\section{Case Presentation}

A 50-year-old woman with confirmed SARS-CoV-2 infection was admitted to a peripheral hospital three weeks prior to admission to our hospital. Because of deterioration of respiratory function, the patient had to be intubated and mechanically ventilated. A CT-scan was performed at this stage revealing spacious areas of ground glass opacities including consolidation and air bronchogram (Fig. 1). As the patient's situation worsened, she was transferred to the University Hospital Innsbruck, a tertiary medical center, for evaluation of extracorporeal membrane oxygenation (ECMO) therapy.

Evaluation of the pulmonary state revealed a moderate, SARS-CoV-2-associated ARDS $\left(\mathrm{paO}_{2} / \mathrm{FiO}_{2}\right.$ ratio of 124) according to Berlin definition [4]. Initially, pressurecontrolled ventilation (PCV) was applied with an Evita ${ }^{\circ}$ Infinity V500 respirator (Dräger, Lübeck, Germany) with a peak inspiratory pressure $\left(\mathrm{P}_{\text {peak }}\right)$ of $27 \mathrm{~cm} \mathrm{H}_{2} \mathrm{O}$, a positive end-expiratory pressure (PEEP) of $12 \mathrm{~cm} \mathrm{H}_{2} \mathrm{O}$, an inspiration to expiration ratio (I:E-ratio) of 1:1, and a respiratory rate of $21 / \mathrm{min}$, resulting in a tidal volume of $5.8 \mathrm{ml} / \mathrm{kg}$ predicted body weight (PBW) and a compliance of $24 \mathrm{ml} / \mathrm{cm} \mathrm{H}_{2} \mathrm{O}$.

In accordance with ELSO guidelines [5], ECMO therapy was declined. Prone position improved the $\mathrm{paO}_{2} /$ $\mathrm{FiO}_{2}$ ratio to $130-150$ and was performed for the next $16 \mathrm{~h}$. After this period compliance worsened again in supine position and invasiveness of ventilation had to be increased $\left(\mathrm{P}_{\text {peak }} 28 \mathrm{~cm} \mathrm{H}_{2} \mathrm{O}\right.$, PEEP $10 \mathrm{~cm} \mathrm{H}_{2} \mathrm{O}$, respiratory rate of $25 / \mathrm{min}$, calculated mechanical power (MP) [6] of $16.9 \mathrm{~J} / \mathrm{min}$ ). Nevertheless, oxygenation was still compromised with a $\mathrm{paO}_{2}$ of $78.2 \mathrm{mmHg}(10.4 \mathrm{kPa})$ at an $\mathrm{FiO}_{2}$ of $0.6\left(\mathrm{paO}_{2} / \mathrm{FiO}_{2}\right.$ ratio of 130$)$.

In an attempt to reduce the invasiveness of ventilation and its deleterious effects on lung tissue flow-controlled ventilation (FCV) was initiated with the Evone ${ }^{\circ}$ respirator (Ventinova Medical B.V., Eindhoven, The Netherlands). This mode of ventilation can be applied via any conventional endotracheal tube and establishes a continuous, constant flow during inspiration as well as expiration, which is monitored and controlled by direct intratracheal pressure measurement. First, identical PCV pressure settings were adopted to FCV with a $\mathrm{P}_{\text {peak }}$ of $28 \mathrm{~cm} \mathrm{H}_{2} \mathrm{O}$, a PEEP of $10 \mathrm{~cm} \mathrm{H}_{2} \mathrm{O}$, an I:E-ratio of 1:1 and the flow set to $12 \mathrm{l} / \mathrm{min}$, otherwise deep sedation (Richmond Agitation-Sedation Scale of -4) was continued with midazolam $0.4-0.5 \mathrm{mg} / \mathrm{kg} / \mathrm{h}$, morphine $0.4 \mathrm{mg} /$ $\mathrm{kg} / \mathrm{h}$ and esketamine $2.1 \mathrm{mg} / \mathrm{kg} / \mathrm{h}$ without the use of neuromuscular blocking agents.

The continuous, constant flow in FCV creates a continuous, stable pressure drop throughout inspiration and expiration from the set and measured tracheal pressure to the alveolar space and vice versa, as there is no pause during the ventilation cycle [7]. As a flow of gas only occurs if a pressure gradient exists, this gradient can be calculated if the flow and the resistance of the system
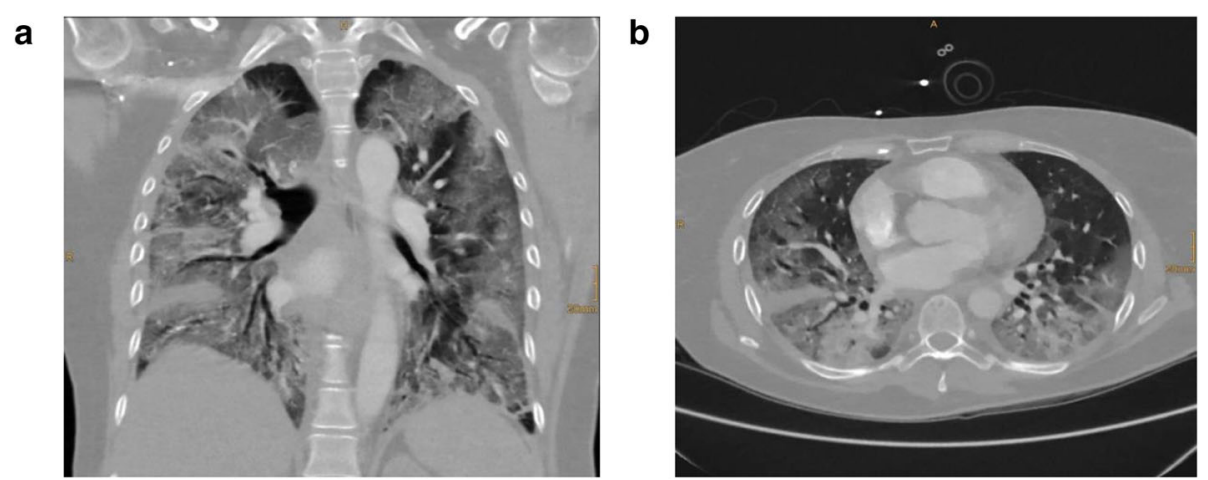

Fig. 1 Computed tomography four days prior to admission showing spacious areas of ground glass opacities including consolidation and air bronchogram (a, coronal plane; b, axial plane, with kind permission of the Department of Radiodiagnostics, Central Hospital Bolzano, Bozen/Bolzano, Italy) 
are known. This relationship is based upon Ohm's law, where the pressure drop $(\Delta \mathrm{P})$ equals the flow () multiplicated by the resistance $(\mathrm{R})$ of the system. Translated to the described patient, a pressure drop of $2.3 \mathrm{~cm} \mathrm{H}_{2} \mathrm{O}$ between the trachea and the alveolar space can be calculated $(\Delta \mathrm{P}=\mathrm{x}$ R; flow $=12 \mathrm{l} / \mathrm{min}=0.2 \mathrm{l} / \mathrm{s}$; resistance $=$ $\left.11.6 \mathrm{~cm} \mathrm{H}_{2} \mathrm{O} / \mathrm{l} / \mathrm{s}\right)$. During inspiration when gas flow is directed to the alveolar space this fact reduced alveolar $\mathrm{P}_{\text {peak }}$ by $2.3 \mathrm{~cm} \mathrm{H}_{2} \mathrm{O}$ (from 28 to $25.7 \mathrm{~cm} \mathrm{H}_{2} \mathrm{O}$ ), whereas during expiration when flow changes direction, PEEP was increased by $2.3 \mathrm{~cm} \mathrm{H}_{2} \mathrm{O}$ (from 10 to $12.3 \mathrm{~cm} \mathrm{H}_{2} \mathrm{O}$ ). Therefore, driving pressure was reduced by $4.6 \mathrm{~cm} \mathrm{H}_{2} \mathrm{O}$ compared to $\mathrm{PCV}$ (from $18 \mathrm{~cm} \mathrm{H}_{2} \mathrm{O}$ to $13.4 \mathrm{~cm} \mathrm{H}_{2} \mathrm{O}$; Fig. 2b). In PCV however, airway pressure is presumed to be equal to alveolar pressure due to a zero flow phase at the end of inspiration as well as expiration, which should result in an equilibrium pressure phase.

After $30 \mathrm{~min}$, blood gas analysis revealed an improvement of oxygenation resulting in a $\mathrm{paO}_{2}$ of $110 \mathrm{mmHg}$ $(14.7 \mathrm{kPa})\left(\mathrm{paO}_{2} / \mathrm{FiO}_{2}\right.$ ratio of 183; Fig. 2c). In order to

\section{a}

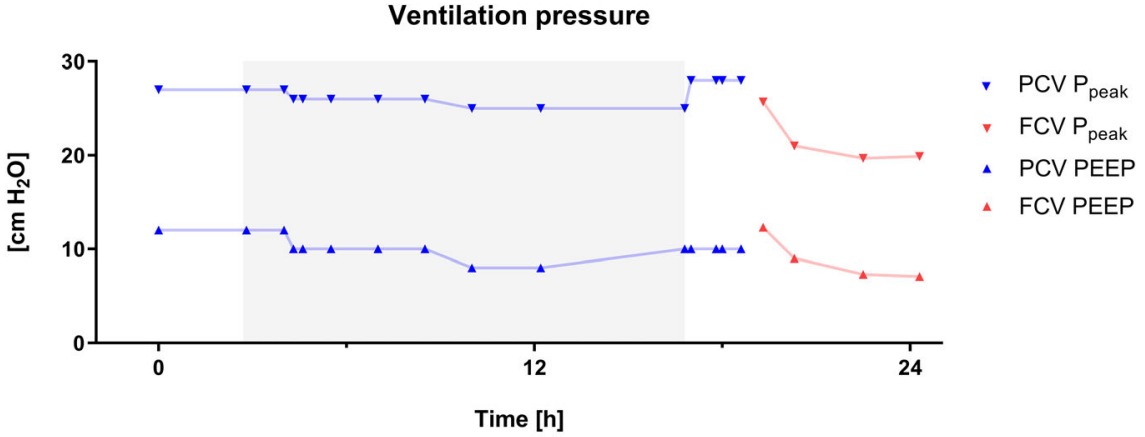

b

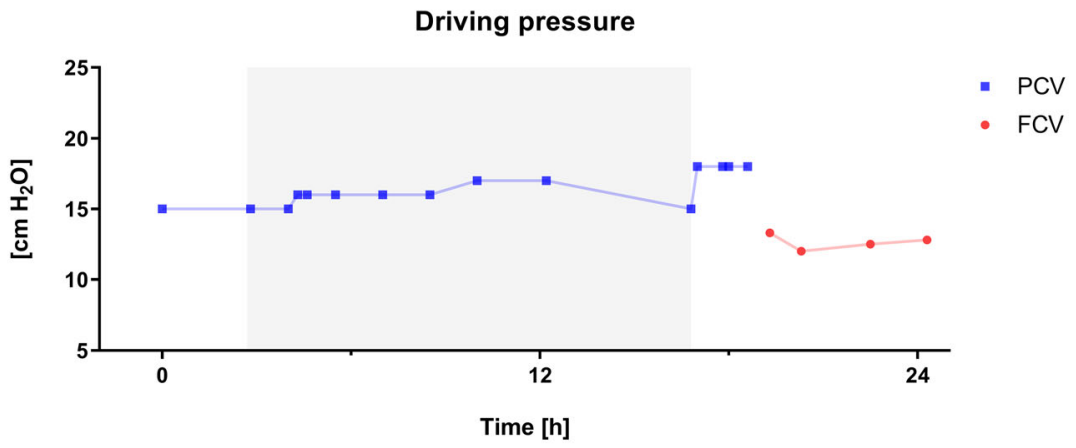

C

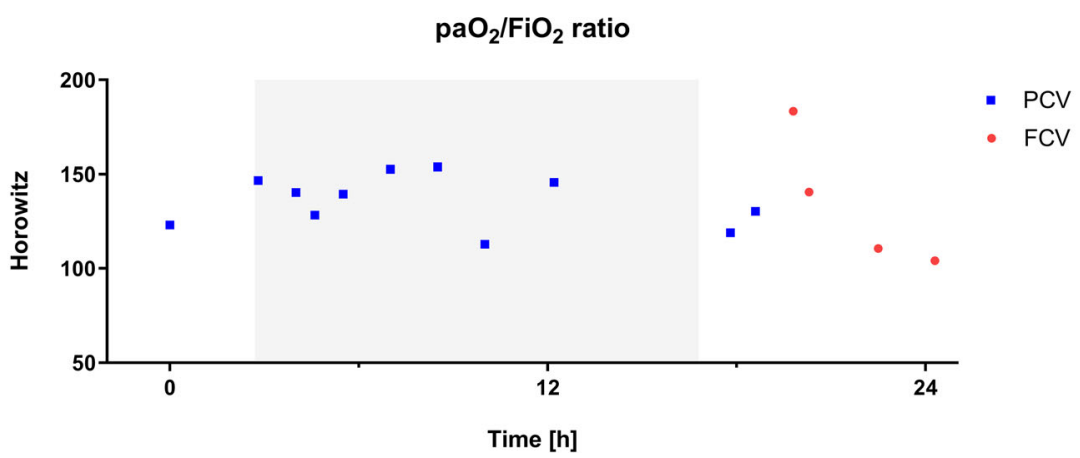

Fig. 2 demonstrates the course of respiratory parameters during pressure-controlled ventilation (PCV; blue) and flow-controlled ventilation (FCV; red) since hospital admission. The grey area indicates prone position of the patient, the white area supine position. For FCV the (effective) alveolar pressures are calculated based on the measured resistance and the set flow according to Ohm's law. $\mathbf{a}$, peak inspiratory pressure ( $\left.P_{\text {peak }}\right)$ and positive end-expiratory pressure (PEEP). $\mathbf{b}$, driving pressure. $\mathbf{c}$, ratio of arterial partial pressure of oxygen $\left(\mathrm{paO}_{2}\right)$ to fraction of inspired oxygen $\left(\mathrm{FiO}_{2}\right)$ 
a

\section{Pressure-Volume Loop}

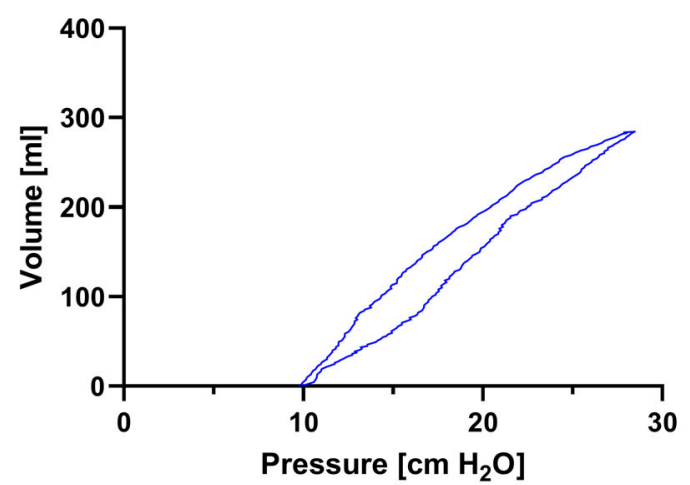

b

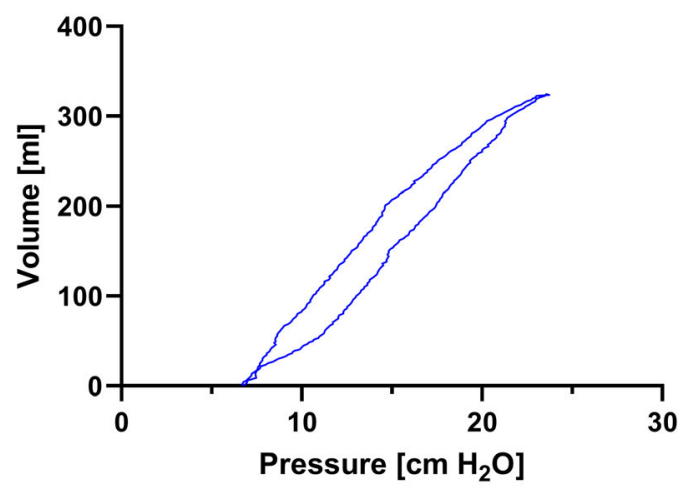

C

Pressure-Volume Loop

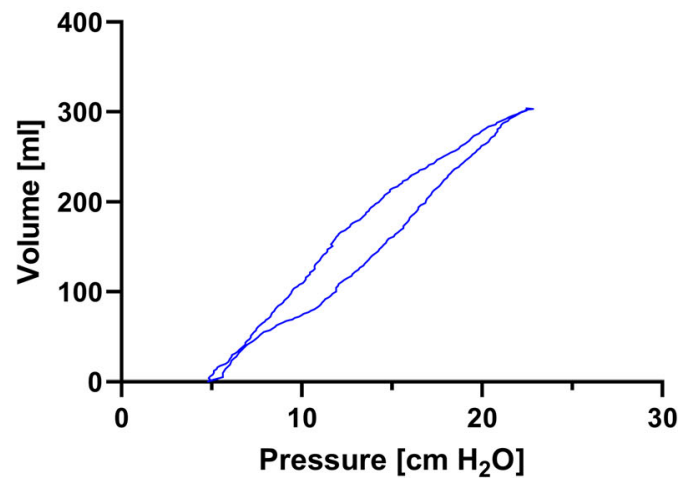

Fig. 3 Pressure-volume loops obtained from intratracheal pressure measurement. $\mathbf{a}$, represents the pressure-volume loop at the beginning of FCV with a peak inspiratory pressure $\left(P_{\text {peak }}\right)$ set to $28 \mathrm{~cm} \mathrm{H}_{2} \mathrm{O}$ and a positive end-expiratory pressure (PEEP) of $10 \mathrm{~cm}$ $\mathrm{H}_{2} \mathrm{O}$. Considering the measured resistance of $11.7 \mathrm{~cm} \mathrm{H} \mathrm{H}_{2} \mathrm{O} / \mathrm{l} / \mathrm{s}$ and the set flow of $12 \mathrm{l} / \mathrm{min}$ and applying Ohm's law, the alveolar $\mathrm{P}_{\text {peak }}$ calculates to only $25.7 \mathrm{~cm} \mathrm{H}_{2} \mathrm{O}$ and the alveolar PEEP to $12.3 \mathrm{~cm}$ $\mathrm{H}_{2} \mathrm{O}$. b, after compliance-guided pressure settings $\mathrm{P}_{\text {peak }}$ was reduced to $23 \mathrm{~cm} \mathrm{H}_{2} \mathrm{O}$ (alveolar $21 \mathrm{~cm} \mathrm{H}_{2} \mathrm{O}$ ) and PEEP $7 \mathrm{~cm} \mathrm{H}_{2} \mathrm{O}$ (alveolar $9 \mathrm{~cm} \mathrm{H}_{2} \mathrm{O}$ ) resulting in an almost linear relation of pressure and volume during in- and expiration. The steeper course of the PV loop in B compared to A indicates the increased compliance after individualized pressure settings. c, two hours after first complianceguided pressure setting, re-evaluation showed a slight decline in

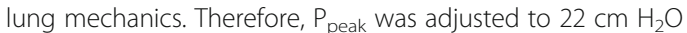
(alveolar $20 \mathrm{~cm} \mathrm{H}_{2} \mathrm{O}$ ) and PEEP to $5 \mathrm{~cm} \mathrm{H}_{2} \mathrm{O}$ (alveolar $7 \mathrm{~cm} \mathrm{H}_{2} \mathrm{O}$ ). The initial kinking of the inspiratory pressure volume curve in $\mathrm{C}$ is an indicator for intratidal recruitment

decrease invasiveness, ventilation settings were then adjusted to dynamic lung mechanics with complianceguided PEEP and peak pressure settings as follows:

First, PEEP level was determined by an incremental (or decremental) PEEP titration, which represents the point of the highest tidal volume or consecutive dynamic compliance at a fixed driving pressure. Subsequently, driving pressure was stepwise increased, as long as tidal volume showed an overproportional increase based on measured dynamic compliance. This strategy allows for a precise determination of the (so-called) lower and upper inflection point during ventilation and leads to an almost linear relationship of pressure and volume during the ventilation cycle within the individual limits of dynamic lung mechanics [8] (Fig. $3 a+b)$. Finally, gas flow was set to achieve a $\mathrm{paCO}_{2}$ level $<60 \mathrm{mmHg}(8.0 \mathrm{kPa})$.

Calculation of alveolar pressure according to Ohm's law revealed a $\mathrm{P}_{\text {peak }}$ of $21 \mathrm{~cm} \mathrm{H}_{2} \mathrm{O}$ and a PEEP of $9 \mathrm{~cm}$ $\mathrm{H}_{2} \mathrm{O}$, thus a driving pressure of $12 \mathrm{~cm} \mathrm{H}_{2} \mathrm{O}$, resulting in a compliance of $27 \mathrm{ml} / \mathrm{cm} \mathrm{H}_{2} \mathrm{O}$ and a calculated MP [9] of $8.6 \mathrm{~J} / \mathrm{min}$ with individualized ventilation settings. Thirty minutes after compliance-guided adjustment $\mathrm{paO}_{2} / \mathrm{FiO}_{2}$ ratio was 140 (Fig. 2b).

Re-evaluation of lung mechanics after two hours allowed for a further reduction of $\mathrm{P}_{\text {peak }}$ to $20 \mathrm{~cm} \mathrm{H}_{2} \mathrm{O}$ and a PEEP of $7 \mathrm{~cm} \mathrm{H}_{2} \mathrm{O}$ (Fig. 2c) resulting in a MP of $7.7 \mathrm{~J} / \mathrm{min}$. However, during a period of four hours after initial assessment of the patient's lung mechanics, the compliance worsened, and subsequently tidal volume decreased from 5.3 to $4.7 \mathrm{ml} / \mathrm{kg}$ PBW with a decline of $\mathrm{paO}_{2}$ to $67.6 \mathrm{mmHg}(9.0 \mathrm{kPa})$ at an $\mathrm{FiO}_{2}$ of $0.65\left(\mathrm{paO}_{2} /\right.$ $\mathrm{FiO}_{2}$ ratio of 104).

Ventilation of the patient was then continued with PCV at significantly increased pressure settings $\left(\mathrm{P}_{\text {peak }} 28 \mathrm{~cm}\right.$ $\mathrm{H}_{2} \mathrm{O}$, PEEP $10 \mathrm{~cm} \mathrm{H}_{2} \mathrm{O}$, respiratory rate $25 / \mathrm{min}$, MP $17.3 \mathrm{~J} / \mathrm{min}$ ) and the patient was put in prone position. In the further course ongoing invasive ventilation led to 
ECMO therapy and unfortunately the patient died two months later due to therapy refractory B-cell depletion and no ability to form antibodies against SARS-CoV-2.

\section{Discussion}

FCV enables a continuous, constant flow not only during inspiration, but also during expiration, which is a novelty in artificial ventilation [10,11]. Steady, slow changes in pressure and volume minimize the mechanical impact of ventilation (i.e. stress and strain) or - in terms of physics - mechanical power and dissipated energy. Previous preclinical $[12,13]$ as well as clinical trials $[14-16]$ with FCV already demonstrated improved lung recruitment and gas distribution, which was hypothesized to be related to flow control and a linearized airway pressure decline during expiration. In our case, this may explain the initial increase in $\mathrm{paO}_{2} / \mathrm{FiO}_{2}$ ratio by $30 \%$ (from 130 to 183 ) with identical ventilation settings as in preceding PCV.

Strictly speaking, due to physical reasons, pressure settings were not the same in PCV and FCV. The continuous, constant flow in FCV results in a pressure drop from the trachea to the alveolar space during inspiration and reversely during expiration. The pressure measured in the trachea and shown on the monitor of the ventilator therefore does not reflect the "true" (= effective) alveolar pressure, which according to Ohm's law must be lower during inspiration and higher during expiration, given that gas flow and resistance of the system are kept constant. This specific physical characteristic must be kept in mind when assessing pressure settings during ventilation with FCV and thus higher driving pressures and lower PEEP levels than generally accepted in PCV [17-20] may be applicable in FCV.

The only uncertainty is the amount of tissue resistance (resulting from e.g. inertia, friction, viscoelasticity) not contributing to the flow-related difference between tracheal and alveolar pressures. In FCV constant in- and expiratory flow allows for more precise resistance measurements at $\mathrm{P}_{\text {peak }}$ (representing airway as well as tissue resistance) as well as PEEP (mainly representing airway resistance) and a well-founded estimation of tissue resistance (as the difference of both values). To keep it simple, in our patient only the resistance measured at $\mathrm{P}_{\text {peak }}$ level was used for conversion of tracheal pressures into (global) alveolar pressures.

Compliance-guided pressure settings aim to reduce both the occurrence of atelectasis and overdistension of lung tissue by adjusting the patient's ventilation between the (so-called) upper and lower inflection point of the individual pressure-volume curve (Fig. $2 \mathrm{a}+\mathrm{b}$ ). Because in FCV the degree of freedom is limited to settings of $\mathrm{P}_{\text {peak }}$, PEEP and gas flow, the administered tidal volume and respiratory rate will automatically adjust depending on the amount of functional lung tissue. This fact is of high importance especially in COVID-19 patients, as they can show quick alterations in lung compliance.

An issue to be discussed is the low PEEP level determined during compliance-guided pressure adjustments, which apparently did not fit the demands of our ARDS patient. Initial rapid improvement of gas exchange after switching from PCV to FCV was probably related to a slight increase in PEEP (with the same PEEP set at the ventilator as during $\mathrm{PCV}$ ) due to the nature of FCV as explained above. However, two hours later PEEP was decreased to $5 \mathrm{~cm} \mathrm{H}_{2} \mathrm{O}$ (corresponding to a PEEP of approximately $7 \mathrm{~cm} \mathrm{H}_{2} \mathrm{O}$ in the alveolar space) after reevaluation of the patient. Finally, the patient's very poor compliance $\left(<20 \mathrm{ml} / \mathrm{cm} \mathrm{H}_{2} \mathrm{O}\right)$ and significantly reduced PEEP level $\left(5 \mathrm{~cm} \mathrm{H}_{2} \mathrm{O}\right)$ resulted in a tidal volume not capable of maintaining sufficient oxygenation $(4.7 \mathrm{ml} / \mathrm{kg}$ PBW). This fact could have been anticipated by examination of the corresponding pressure-volume (PV) loops, which upon detailed analysis indicated alveolar collapse at the end of expiration and subsequent initial alveolar recruitment during inspiration (initial kinking of the inspiratory pressure volume curve, Fig. 3c).

Unfortunately, the PV loop feature is not implemented in the respirator's software yet which undoubtedly would be very helpful to monitor undesired changes in dynamic lung mechanics in critically ill patients.

\section{Conclusions}

In FCV due to constant flow, monitored tracheal pressure does not reflect the pressure at the alveolar space and thus higher driving pressures and lower PEEP levels than generally accepted may be applicable. Additionally, in FCV individualization of ventilation settings based on dynamic compliance measurements is possible, even though it needs constant reevaluation of the patient's lung mechanics and a prompt adjustment of ventilator settings if it becomes clear that the severity of the pulmonary disease impedes a lung-protective ventilation strategy. Under these circumstances increased driving pressures or PEEP levels above lung mechanic limits and/or an increased fraction of inspired oxygen must be accepted. This case may demonstrate the limits of a lung-protective ventilation strategy in ARDS and highlights the complexity of this disease. However, FCV might offer a clinical applicable approach to reduce applied and dissipated energy of artificial ventilation in order to improve the outcome in COVID-19 patients requiring prolonged ventilation.

\section{Abbreviations}

ARDS: Acute repiratory distress syndrome; COVID-19: Corona virus disease 2019; CT: Computed tomography; ECMO: Extracorporeal membrane oxygenation; ELSO: Extracorporeal life support organisation; FCV: Flowcontrolled ventilation; FiO2: Fraction of inspired oxygen; I:E: Inspiration to expiration ratio; MP: Mechanical power; $\mathrm{paCO}_{2}$ : Arterial partial pressure of carbon dioxide; $\mathrm{paO}_{2}$ : Arterial partial pressure of oxygen; PBW: Predicted 
body weight; PCV: Pressure controlled ventilation; PEEP: Positive endexpiratory pressure; PV Loop: Pressure volume loop; R: Resistance; $\dot{V}: .$. Flow; $\Delta P$ : Pressure difference

\section{Acknowledgements}

We would like to thank Prof. Dietmar Enk and Prof. Tom Barnes for teaching us flow-controlled ventilation and sharing their profound knowledge with us We also thank them for providing the PV-loops from the logged data of the Evone $^{\circledast}$ respirator and reviewing our manuscript.

\section{Authors' contributions}

PS, GP, SM and RB implemented FCV ventilation at the intensive care unit of the Medical University Innsbruck during the current COVID-19 pandemic and shared their experience. PS, JA, GP and JM are currently executing several preclinical as well as clinical studies with FCV and shared their experience as well. BG interpreted the findings of the computed tomography. PS and JM created graphs for data presentation and wrote the manuscript. All authors contributed to the discussion, read, and approved the final manuscript.

\section{Funding}

This case report received funding from the European Union's Horizon 2020 research and innovation programme under grant agreement No 961787.

\section{Availability of data and materials}

The datasets used and analyzed are available from the corresponding author on reasonable request.

\section{Declarations}

Ethics approval and consent to participate

Not applicable.

\section{Consent for publication}

The patient's relatives gave their written consent for publication, because the patient did not regain consciousness.

\section{Competing interests}

The authors declare that they have no competing interests.

\section{Author details}

${ }^{1}$ Department of Anaesthesiology and Intensive Care Medicine, Medical University Innsbruck, Innsbruck, Austria. ${ }^{2}$ Department of Radiology, Medical University Innsbruck, Innsbruck, Austria.

Received: 12 February 2021 Accepted: 5 May 2021

Published online: 12 May 2021

\section{References}

1. Gattinoni L, Chiumello D, Caironi P, et al. COVID-19 pneumonia: different respiratory treatments for different phenotypes? Intensive Care Med. 2020; 46(6):1099-102.

2. Gattinoni L, Chiumello D, Rossi S. COVID-19 pneumonia: ARDS or not? Crit Care. 2020;24(1):154

3. Marini JJ, Gattinoni L. Management of COVID-19 respiratory distress [published online ahead of print, 2020 Apr 24]. JAMA. 2020. https://doi. org/10.1001/jama.2020.6825.

4. ARDS Definition Task Force, Ranieri VM, Rubenfeld GD, et al. Acute respiratory distress syndrome: The berlin definition. JAMA. 2012;307(23): 2526-33.

5. Bartlett RH, Ogino MT, Brodie D, et al. Initial ELSO guidance document: ECMO for COVID-19 patients with severe cardiopulmonary failure. ASAIO J. 2020:66(5):472-4.

6. Serpa Neto A, Deliberato RO, Johnson AEW, et al. PROVE Network Investigators. Mechanical power of ventilation is associated with mortality in critically ill patients: an analysis of patients in two observational cohorts. Intensive Care Med. 2018;44(11):1914-22.

7. Enk D, Spraider P, Abram J, Barnes T. Pressure Measurements in FlowControlled Ventilation. Crit Care Med. 2020;48(12):e1359-60.

8. Spraider P, Martini J, Abram J, et al. Individualized flow-controlled ventilation compared to best clinical practice pressure-controlled ventilation: a prospective randomized porcine study. Crit Care. 2020;24(1): 662.

9. Gattinoni L, Tonetti T, Cressoni M, et al. Ventilator-related causes of lung injury: the mechanical power. Intensive Care Med. 2016;42(10):1567-75.

10. Barnes T, van Asseldonk D, Enk D. Minimisation of dissipated energy in the airways during mechanical ventilation by using constant inspiratory and expiratory flows - Flow-controlled ventilation (FCV). Med Hypotheses. 2018; 121:167-76

11. Barnes T, Enk D. Ventilation for low dissipated energy achieved using flow control during both inspiration and expiration. Trends Anaesth Crit Care. 2019;24:5-12.

12. Schmidt J, Wenzel C, Mahn M, et al. Improved lung recruitment and oxygenation during mandatory ventilation with a new expiratory ventilation assistance device: A controlled interventional trial in healthy pigs. Eur J Anaesthesiol. 2018;35(10):736-44

13. Schmidt J, Wenzel C, Spassov S, et al. Flow-controlled ventilation attenuates lung injury in a porcine model of acute respiratory distress syndrome: a preclinical randomized controlled study. Crit Care Med. 2020;48(3):e241-8.

14. Schmidt J, Günther F, Weber J, et al. Glottic visibility for laryngeal surgery: Tritube vs. microlaryngeal tube: a randomised controlled trial. Eur J Anaesthesiol. 2019;36(12):963-71.

15. Weber J, Schmidt J, Straka L, Wirth S, Schumann S. Flow-controlled ventilation improves gas exchange in lung-healthy patients- a randomized interventional cross-over study. Acta Anaesthesiol Scand. 2020;64(4):481-8.

16. Weber J, Straka L, Borgmann S, Schmidt J, Wirth S, Schumann S. Flowcontrolled ventilation (FCV) improves regional ventilation in obese patients a randomized controlled crossover trial. BMC Anesthesiol. 2020;20(1):24.

17. Amato MB, Meade MO, Slutsky AS, et al. Driving pressure and survival in the acute respiratory distress syndrome. N Engl J Med. 2015;372(8):747-55.

18. Briel M, Meade M, Mercat A, et al. Higher vs lower positive end-expiratory pressure in patients with acute lung injury and acute respiratory distress syndrome: systematic review and meta-analysis. JAMA. 2010;303(9):865-73.

19. Walkey AJ, Del Sorbo L, Hodgson CL, et al. Higher PEEP versus lower PEEP Strategies for patients with acute respiratory distress syndrome. A systematic review and meta-analysis. Ann Am Thorac Soc. 2017;14:297-303.

20. Alhazzani W, Møller MH, Arabi YM, et al. Surviving sepsis campaign: guidelines on the management of critically III adults with coronavirus disease 2019 (COVID-19). Crit Care Med. 2020;48(6):e440-69.

\section{Publisher's Note}

Springer Nature remains neutral with regard to jurisdictional claims in published maps and institutional affiliations.
Ready to submit your research? Choose BMC and benefit from:

- fast, convenient online submission

- thorough peer review by experienced researchers in your field

- rapid publication on acceptance

- support for research data, including large and complex data types

- gold Open Access which fosters wider collaboration and increased citations

- maximum visibility for your research: over $100 \mathrm{M}$ website views per year

At $\mathrm{BMC}$, research is always in progress.

Learn more biomedcentral.com/submissions 